Syntax Fusion: Jurnal Nasional Indonesia

e-ISSN: 2775-4440

Vol. 1, No. 10, Oktober 2021

\title{
SISTEM INFORMASI INVENTORY GUDANG BERBASIS WEB DI RESTORAN ASEP STROBERI LEMBANG
}

\author{
Alvan Adhitia Pangestu, Deden, Rini Suwartika Kusumadiarti \\ Diploma Manajemen Informatika, Politeknik Piksi Ganesha, Indonesia, \\ Email: Alvanpangestu257@gmail.com, Dedensatrio2@gmail.com, \\ rini.suwartika@gmail.com
}

\begin{abstract}
Abstrak
Sistem inventaris item sangat penting bagi perusahaan karena setiap hari pasti akan memiliki mutasi barang yang terus berjalan. Restoran Liwet Asep Strawberry Lembang adalah perusahaan di bidang memasak Sunda di Lembang. Berdasarkan pengamatan diketahui bahwa sistem inventaris di restoran ini masih menggunakan sistem manual menggunakan Microsoft Excel. Tujuan peneliti adalah untuk membuat aplikasi inventaris yang memfasilitasi proses data mutasi dalam item keluar dengan barang keluar, dan sehingga data lebih akurat antara stok dalam sistem dengan stok fisik di gudang. Metode pengembangan perangkat lunak menggunakan metodologi air terjun. Hasil akhir dari penelitian ini adalah dalam bentuk aplikasi inventaris web dengan bahasa pemrograman PHP dan MySQL yang dapat diterapkan di restoran Liwet Asep Lembang. Dengan adanya sistem inventaris gudang berbasis web, dapat memudahkan perusahaan dalam memasukkan data yang pada awalnya secara manual sekarang terkomputerisasi, sehingga menghemat lebih dan efisien.
\end{abstract}

Kata Kunci: Sistem Inventory; PHP; MYSQL

Diterima: 25-09-2021 Direvisi: 15-10-2021 Disetujui: 18-10-2021

\section{Pendahuluan}

Saat ini teknologi tumbuh sangat cepat, termasuk di bidang informatika. Hal ini disebabkan banyak inovasi yang telah dirancang dan kemudian dikembangkan untuk memfasilitasi kehidupan sehari-hari (Indrajit, 2001). Seiring dengan perkembangan teknologi cepat ini dari waktu ke waktu, buat semua pekerjaan yang bisa dilakukan dengan efektif dan efisien. Karena sebagian besar perusahaan masih menggunakan sistem persediaan barang dengan sistem manual. Dengan teknologi komputerisasi yang sangat cepat, ia dapat memudahkan memasukkan barang atau merekam ketersediaan suatu barang dan dapat memperbarui stok barang dan stok barang keluar secara otomatis (Roosdhani, Wibowo, \& Widiastuti, 2012) 
Sistem aplikasi inventaris sangat penting bagi perusahaan untuk mendapatkan perhitungan dan estimasi jumlah optimal (Juwari, 2018) Sistem inventaris item dapat dibuat menggunakan PHP dan mySQL. PHP adalah salah satu bahasa pemrograman skrip yang dirancang untuk membangun aplikasi web. PHP digunakan ketika disebut program browser web otomatis yang ditulis dengan PHP akan diuraikan di server Web oleh PHP Interpreter dan dapat diterjemahkan ke dalam dokumen HTML, yang kemudian akan ditampilkan lagi di server web (Putri, 2018)

SQL saya adalah sistem manajemen basis data relasional yang berarti data yang dapat dikelola dalam database yang akan ditempatkan di beberapa tabel terpisah sehingga manipulasi data akan lebih cepat (Kartiwan, 2019)

Restoran Liwet Asep Strawberry Lembang adalah perusahaan di bidang memasak Sunda yang sangat terkenal di Lembang (RISWANTO, 2018) Berdasarkan pengamatan diketahui bahwa sistem persediaan barang di restoran ini masih menggunakan sistem manual menggunakan Microsoft Excel, ini tentu sangat tidak efektif dan efisien. Menurut rencana peneliti dengan menciptakan aplikasi persediaan barang menggunakan PHP dan mySQL. Dengan sistem ini, diharapkan dapat membantu proses data mutasi dalam item dan barang keluar sehingga data lebih akurat antara stok dalam sistem dengan stok fisik di gudang.

\section{Metode Penelitian}

Dalam pengembangan sistem yang dibangun peneliti menggunakan alat bantu berupa teknik pengumpulan data yang digunakan pada saat penelitian yang terdiri dari pengamatan dan wawancara. Dalam metode observasi ini peneliti melakukan survei lokasi untuk mengumpulkan data data yang berkaitan dengan inventaris barang di restoran Liwet Asep Strawberry Lembang. (Moses \& Knutsen, 2019)

Pada tahap wawancara, peneliti melakukan wawancara terhadap manajer umum restoran Liwet Asep Lembang Strawberry dan kepala gudang untuk mencari tahu informasi tentang masalah yang terjadi dalam proses inventaris item (Yuhana \& Aminy, 2019). Metode pengembangan perangkat lunak yang digunakan peneliti adalah metodologi air terjun, karena dengan metode air terjun ini dapat membuat sistem informasi dapat diatur secara teratur dan dapat mengetahui kesalahan dan dapat segera memperbaikinya (Rini Asmara, n.d.)

\section{Hasil dan Pembahasan}

\section{Tahap Pengembangan}

Tahap pengembangan yaitu memahami perangkat lunak secara detail, dengan melakukan pendefinisian dengan struktur datanya. Diagram alir data (Pengampu et al., n.d.) adalah suatu diagram yang menggambarkan aliran data dari sebuah proses atau sistem. DFD juga menyediakan informasi mengenai luaran dan masukan dari setiap entitas dan proses itu sendiri. DFD tidak memiliki kontrol terhadap alirannya, tidak ada aturan mengenai keputusan maupun pengulangan. 


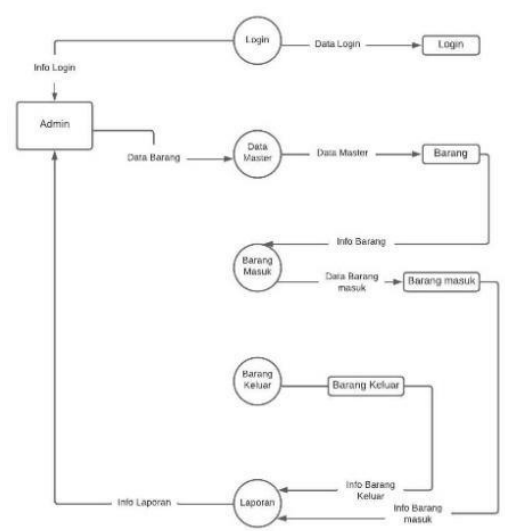

\section{Gambar 2. Data Flow Diagram (DFD)}

\section{Implementasi Sistem}

Berikut ini adalah implementasi sistem untuk aplikasi sistem informasi inventory gudang.

a. Tampilan form login

Tampilan menu login adalah tampilan pertama dari pengguna, dalam tampilan ini, baik pengguna biasa dan admin melakukan proses login. Aplikasi ini hanya dapat digunakan oleh dua pengguna, yaitu Admin Gudang dan Manajer Perusahaan.

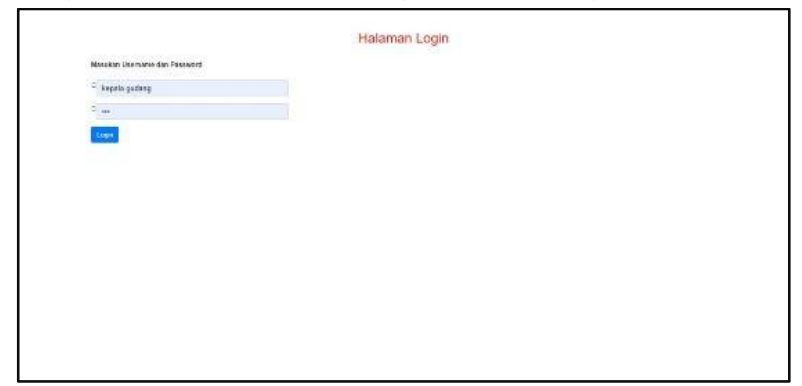

Gambar 3. Form Login Aplikasi

b. Tampilan Menu Utama

Pada halaman menu utama ini, baik user maupun admin dapat mengakses data yang ada dengan memilih beberapa menu seperti:

Master menu, subwater meliputi: item stok, pengguna, entri data. Pengguna semua menu pengguna, berisi jumlah pengguna yang dapat mengakses ke dalam aplikasi, termasuk: Admin Gudang, Manajer dan Kepala Gudang. Semua menu barang, menutupi semua barang masuk dan keluar. Menu data unit, dalam bentuk menu yang digunakan untuk menghitung dan memisahkan barang dalam jumlah unit misalnya: kg, pcs, dasi dan bungkus.

Menu Rak Data, berisi menu untuk memisahkan item sesuai dengan jenisnya. Menu Laporan Barang Ingoing, sweater berisi laporan item dan formulir mencetak laporan item. Laporan Item Keluar menu, subwiter menyertakan laporan barang keluar dan bentuk cetak barang-barang Laporan. Menu Item adalah semua, subpenerasi subwitten termasuk item input. Menu item adalah semua, menu supply termasuk input clergy. 


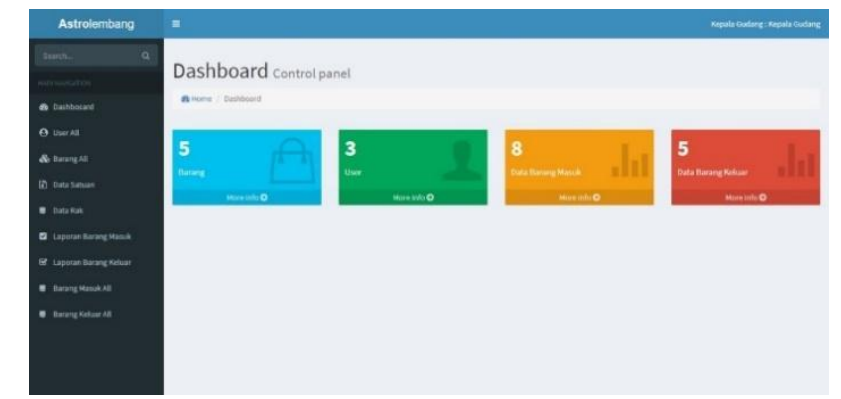

Gambar 4. Form menu utama

1. Tampilan User All

Form ini memberikan informasi kepada manajer perusahaan atau pihak yang bersangkutan mengenai siapa saja yang bisa mengakses dan terhubung dengan aplikasi

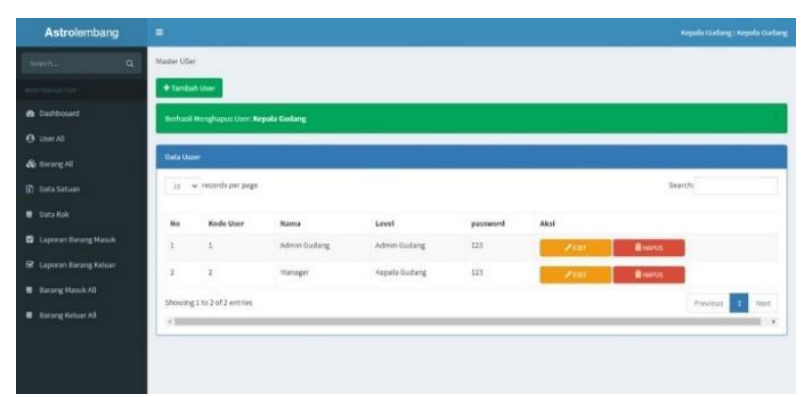

\section{Gambar 5. Form User All}

2. Barang All

Form ini meliputi informasi stok barang yang ada di gudang lengkap dengan jenis barang, satuan, stok dan nama rak

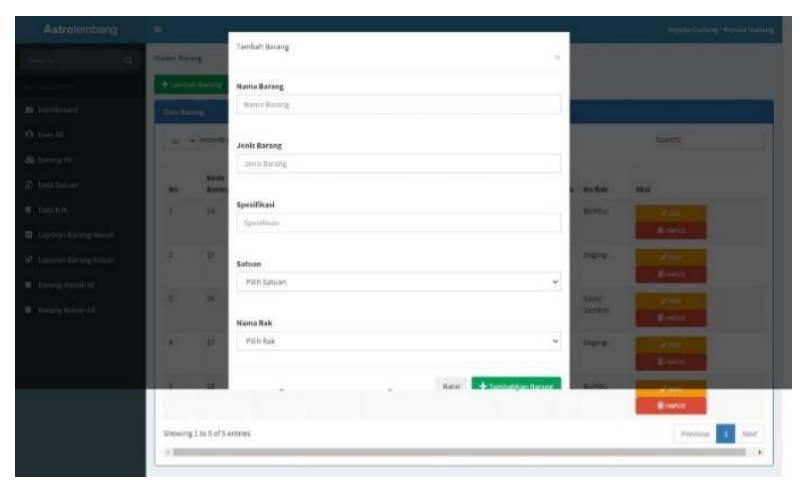

Gambar 6. Form Barang All

\section{Form Data Satuan}

Form ini digunakan untuk menginput data satuan barang meliputi, Kilogram (Kg), ikat, pcs dan lainnya disesuaikan dengan kebutuhan perusahaan. 
Sistem Informasi Inventory Gudang Berbasis Web Di Restoran Asep Stroberi Lembang

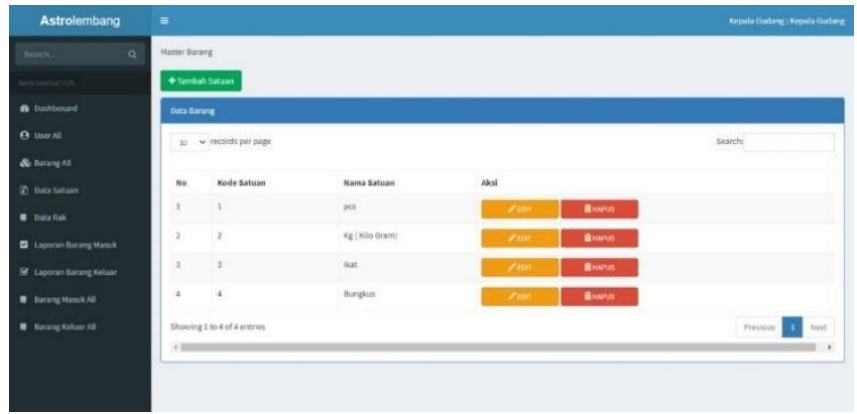

Gambar 7. Form Data Satuan

4. Form Data Rak

Form ini digunakan untuk menginput jenis-jenis barang dan memisahkan barang tersebut sesuai dengan kebutuhan perusahaan

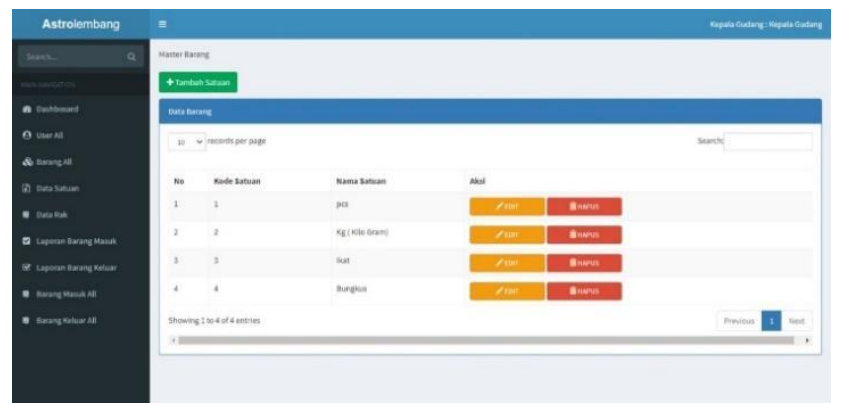

\section{Gambar 8. Form Data Rak}

5. Form Laporan Barang Masuk

Form ini dapat mencakup semua informasi yang berkaitan dengan semua barang yang masuk secara lengkap, dan dapat langsung dicetak untuk selanjutnya digunakan sebagai informasi perusahaan.

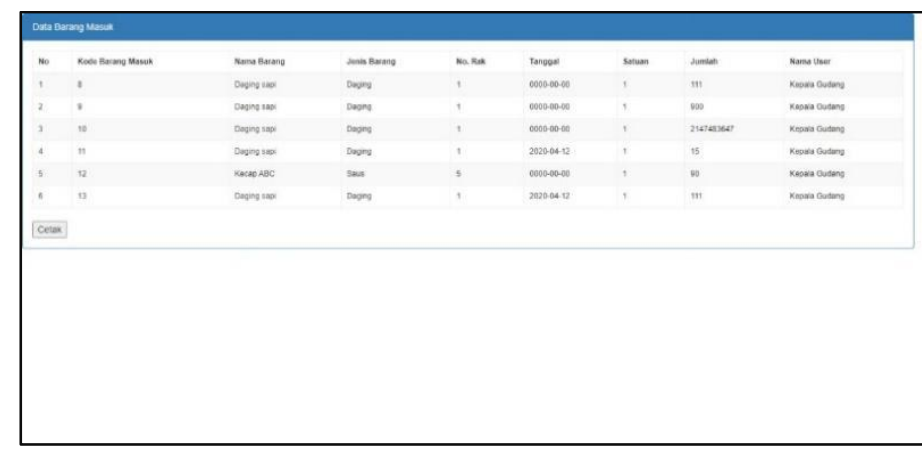

Gambar 9. Form laporan Barang Masuk

6. Laporan Barang Keluar

Bentuk ini hampir sama dengan formulir laporan masuk, I.E. Formulir ini dapat mencakup semua informasi yang dengan semua item yang keluar 
penuh, dan dapat langsung dicetak untuk digunakan sebagai informasi perusahaan.

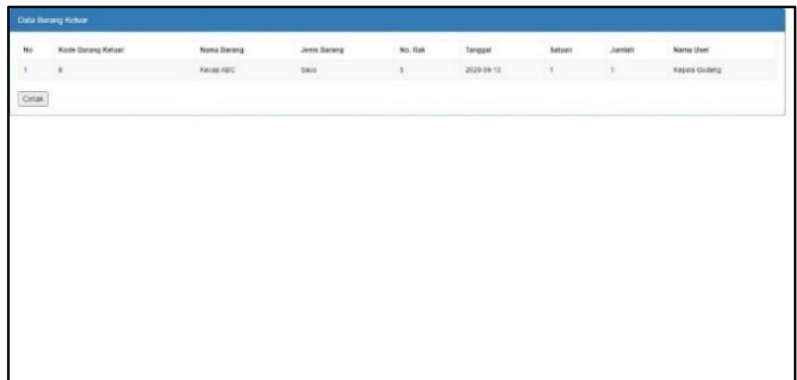

\section{Gambar 10. Form laporan Barang Keluar}

7. Form Barang Masuk All

Formulir ini digunakan untuk memasukkan item yang memasuki gudang yang tentu saja nama item tersedia di gudang.

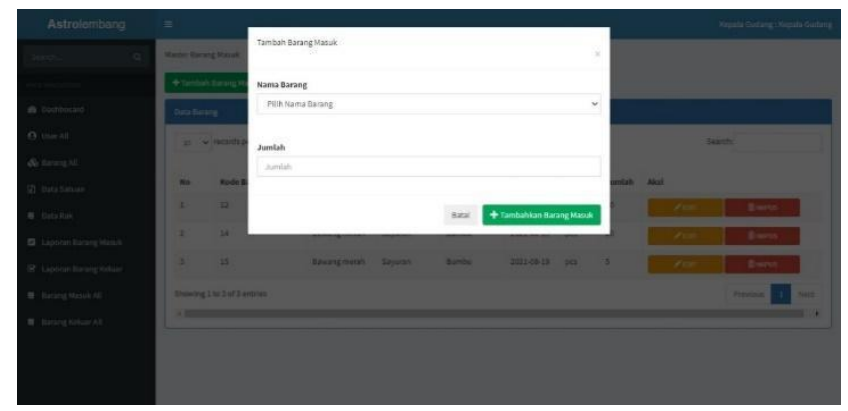

Gambar 11. Form laporan Masuk All

\section{Form Barang Keluar All}

Form ini digunakan untuk menginput data barang yang keluar dari gudang, dengan nama barang yang sudah tersedia di bagian gudang tersebut.

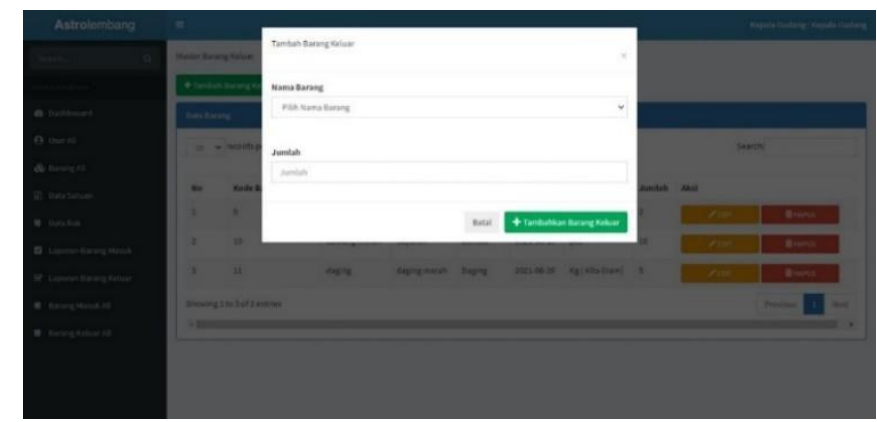

Gambar 12. Form laporan Keluar All 
9. Form Update User

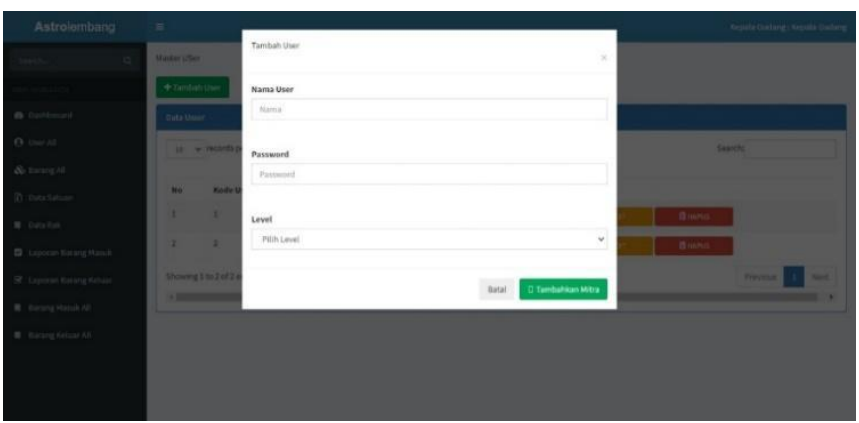

\section{Gambar 13. Form Update User}

\section{Hasil Pengujian Penelitian}

Menurut Pressman di (Khasanah, Kesuma, \& Wijianto, 2018), pengujian blackbox adalah tes yang memungkinkan insinyur perangkat lunak untuk mendapatkan serangkaian kondisi input yang sepenuhnya menggunakan semua persyaratan fungsional untuk suatu program.

Tabel 1. Hasil Pengujian dari Berbagai Versi

\begin{tabular}{clcc}
\hline No. & \multicolumn{1}{c}{ Nama } & Spesifikasi & Kesimpulan \\
\hline 1 & HP Pavilion & Procesor i5, RAM 4 GB, & Aplikasi berjalan baik \\
& g4 & Hardisk & \\
& & 250 GB, Windows 10 & \\
\hline
\end{tabular}

Tabel 2. Hasil uji Coba Black Box

\begin{tabular}{|c|c|c|c|}
\hline Halaman & Yang Diuji & Status & Hasil \\
\hline Halaman Login & $\begin{array}{l}\text { Tombol } \\
\text { Login }\end{array}$ & Berhasil & $\begin{array}{l}\text { Berhasil masuk ke menu } \\
\text { utama }\end{array}$ \\
\hline \multirow{4}{*}{ Dashboard } & $\begin{array}{l}\text { Tombol } \\
\text { Barang }\end{array}$ & Berhasil & $\begin{array}{l}\text { Berhasil masuk ke menu } \\
\text { master barang }\end{array}$ \\
\hline & Tombol User & Berhasil & $\begin{array}{c}\text { Berhasil masuk ke menu } \\
\text { daftar user }\end{array}$ \\
\hline & $\begin{array}{r}\text { Tombol Data } \\
\text { barang masuk }\end{array}$ & Berhasil & $\begin{array}{l}\text { Berhasil masuk ke info } \\
\text { barang masuk }\end{array}$ \\
\hline & $\begin{array}{c}\text { Tombol Data } \\
\text { Barang } \\
\text { Keluar }\end{array}$ & Berhasil & $\begin{array}{l}\text { Berhasil masuk ke info } \\
\text { barang keluar }\end{array}$ \\
\hline \multirow{2}{*}{ User All } & $\begin{array}{c}\text { Tombol } \\
\text { Tambah User }\end{array}$ & Berhasil & $\begin{array}{l}\text { Berhasil Menambah Data } \\
\text { User }\end{array}$ \\
\hline & $\begin{array}{l}\text { Kolom } \\
\text { Search }\end{array}$ & Berhasil & Berhasil mencari data user \\
\hline
\end{tabular}




\begin{tabular}{|c|c|c|c|}
\hline & Tombol Edit & Berhasil & Berhasil mengedit data user \\
\hline & $\begin{array}{l}\text { Tombol } \\
\text { Hapus }\end{array}$ & Berhasil & $\begin{array}{c}\text { Berhasil menghapus data } \\
\text { user }\end{array}$ \\
\hline \multirow{4}{*}{ Barang All } & $\begin{array}{l}\text { Tombol } \\
\text { Tambah } \\
\text { Barang }\end{array}$ & Berhasil & $\begin{array}{l}\text { Berhasil Menambah Data } \\
\text { Barang }\end{array}$ \\
\hline & Tombol Edit & Berhasil & $\begin{array}{c}\text { Berhasil mengedit data } \\
\text { Barang }\end{array}$ \\
\hline & $\begin{array}{l}\text { Tombol } \\
\text { Hapus }\end{array}$ & Berhasil & $\begin{array}{l}\text { Berhasil Menghapus data } \\
\text { barang }\end{array}$ \\
\hline & $\begin{array}{l}\text { Kolom } \\
\text { Search }\end{array}$ & Berhasil & $\begin{array}{l}\text { Berhasil Menghapus data } \\
\text { barang }\end{array}$ \\
\hline \multirow{3}{*}{$\begin{array}{l}\text { Halaman Data } \\
\text { Satuan }\end{array}$} & $\begin{array}{c}\text { Tombol } \\
\text { Tambah } \\
\text { satuan }\end{array}$ & Berhasil & $\begin{array}{l}\text { Berhasil menambah data } \\
\text { satuan barang }\end{array}$ \\
\hline & Tombol Edit & Berhasil & $\begin{array}{l}\text { Berhasil mengedit data } \\
\text { satuan barang }\end{array}$ \\
\hline & $\begin{array}{l}\text { Tombol } \\
\text { Hapus }\end{array}$ & Berhasil & $\begin{array}{l}\text { Berhasil menghapus data } \\
\text { satuan }\end{array}$ \\
\hline \multirow{4}{*}{$\begin{array}{l}\text { Halaman Data } \\
\text { Rak }\end{array}$} & $\begin{array}{l}\text { Tombol } \\
\text { Tambah } \\
\text { Barang }\end{array}$ & Berhasil & $\begin{array}{l}\text { Berhasil Menambah Data } \\
\text { Barang }\end{array}$ \\
\hline & Tombol Edit & Berhasil & $\begin{array}{l}\text { Berhasil mengedit data } \\
\text { Barang }\end{array}$ \\
\hline & $\begin{array}{l}\text { Tombol } \\
\text { Hapus }\end{array}$ & Berhasil & $\begin{array}{l}\text { Berhasil Menghapus data } \\
\text { barang }\end{array}$ \\
\hline & $\begin{array}{l}\text { Kolom } \\
\text { Search }\end{array}$ & Berhasil & $\begin{array}{l}\text { Berhasil Menghapus data } \\
\text { barang }\end{array}$ \\
\hline $\begin{array}{c}\text { Halaman Laporan } \\
\text { Barang Masuk }\end{array}$ & Tombol cetak & Berhasil & $\begin{array}{c}\text { Berhasil masuk ke halaman } \\
\text { Print out }\end{array}$ \\
\hline $\begin{array}{c}\text { Halaman Laporan } \\
\text { Barang Keluar }\end{array}$ & Tombol cetak & Berhasil & $\begin{array}{c}\text { Berhasil masuk ke halaman } \\
\text { Print out }\end{array}$ \\
\hline \multirow{3}{*}{$\begin{array}{l}\text { Halaman Barang } \\
\text { Masuk All }\end{array}$} & $\begin{array}{l}\text { Tombol } \\
\text { Tambah } \\
\text { Barang }\end{array}$ & Berhasil & $\begin{array}{l}\text { Berhasil Menambah Data } \\
\text { Barang }\end{array}$ \\
\hline & Tombol Edit & Berhasil & $\begin{array}{l}\text { Berhasil mengedit data } \\
\text { Barang }\end{array}$ \\
\hline & $\begin{array}{l}\text { Tombol } \\
\text { Hapus }\end{array}$ & Berhasil & $\begin{array}{l}\text { Berhasil Menghapus data } \\
\text { barang }\end{array}$ \\
\hline
\end{tabular}


Sistem Informasi Inventory Gudang Berbasis Web Di Restoran Asep Stroberi Lembang

\begin{tabular}{cccc}
\hline & $\begin{array}{c}\text { Kolom } \\
\text { Search }\end{array}$ & Berhasil & $\begin{array}{c}\text { Berhasil Menghapus data } \\
\text { barang }\end{array}$ \\
\hline & $\begin{array}{c}\text { Tombol } \\
\text { Tambah } \\
\text { Barang }\end{array}$ & Berhasil & $\begin{array}{c}\text { Berhasil Menambah Data } \\
\text { Barang }\end{array}$ \\
\cline { 2 - 4 } Halaman Keluar \\
All & Tombol Edit & Berhasil & $\begin{array}{c}\text { Berhasil mengedit data } \\
\text { Barang }\end{array}$ \\
\cline { 2 - 4 } & $\begin{array}{c}\text { Tombol } \\
\text { Hapus }\end{array}$ & Berhasil & $\begin{array}{c}\text { Berhasil Menghapus data } \\
\text { barang }\end{array}$ \\
& $\begin{array}{c}\text { Kolom } \\
\text { Search }\end{array}$ & Berhasil & $\begin{array}{c}\text { Berhasil Menghapus data } \\
\text { barang }\end{array}$ \\
\hline
\end{tabular}

\section{Kesimpulan}

Berdasarkan hasil penelitian yang dilakukan, dapat disimpulkan bahwa meningkatkan keakuratan informasi tentang jumlah persediaan barang di restoran Lembang Strawberry Asep yang mencegah terjadinya barang-barang kosong. Selanjutnya, membuatnya lebih mudah bagi perusahaan dalam data memasukkan yang awalnya pembukuan sekarang terkomputerisasi, sehingga dapat menghemat lebih banyak biaya dan efisien. Yang terakhir adalah informasi data menjadi lebih rapi dan lebih mudah ditemukan. 
Alvan Adhitia Pangestu, Deden, Rini Suwartika Kusumadiarti

\section{BIBLIOGRAFI}

Moses, Tl Klutsen, (2019) Ways of knowing: Competing methodologies in social and political research. Google Scholar.

Pengampu, D., Yananto, Putra, M., \& Si, M. (N.D.). Tugas Sistem Informasi Akuntansi Diagram Aliran Data Untuk Perusahaan Kecil Disusun Oleh: Soffie Lianti Safitri Nim: 33219010015 Fakultas/Prodi : Ekonomi Dan Bisnis/D3 Akuntansi. Google Scholar.

Pramono, E. (2018). Analisis Sistem Inventory Manajemen Dengan Metode Economic Order Quantity (Eoq). Jurnal Sistem Informasi Ilmu Komputer Prima, 2(1). Google Scholar.

Rifqy, M., Purwo, R., Wibowo, A., Widiastuti, A., Roosdhani, M. R., Purwo), Program), Manajemen, S., Nahdlatul, S., \& Jepara, U. (N.D.). Analisis Tingkat Penggunaan Teknologi Informasi Dan Komunikasi Pada Usaha Kecil Menengah Di Kab. Jepara. Google Scholar.

Rini Asmara, S. K. M. K. (N.D.). Jurnal J-Click Vol 3 No 2 Desember 2016 Issn : 2355 7958 E-Issn : 2541-2469. Google Scholar.

Rizky Kartiwan. (2019). Aplikasi Pengelolaan Dokumen Berbasis Web Menggunakan Php Dan Mysql Dengan Menggunakan Metode Prototype. Google Scholar.

Supomo dan Putratama, (2018) Pengembangan learning management system menggunakan framework codeigniter dan angularjs di PT. XYZ, Jurnal Sistem Informasi. Google Scholar.

Tashikawa, I., Syakhroni, A., \& Abizar Fahri, M. (N.D.). Evolusi Perkembangan Teknologi Informasi Related Papers PengantAr Kuliah Umum Pengant Ar Konsep Dasar Sist Em Dan Teknologi Informasi Richardus Eko Indrajit. Google Scholar.

Y. Riswanto, (2018) Pengaruh Citra Merek Dan Kualitas Pelayanan Terhadap Kepuasan Konsumen, Jurnal Eprint, Google Scholar.

Yuhana, A. N., \& Aminy, F. A. (2019). Optimalisasi Peran Guru Pendidikan Agama Islam Sebagai Konselor Dalam Mengatasi Masalah Belajar Siswa. Jurnal Penelitian Pendidikan Islam, 7(1), 79. https://doi.org/10.36667/jppi.v7i1.357 Google Scholar. 